\title{
Validating Antecedents of Customer Engagement in Social Networking Sites using Fuzzy Delphi Analysis
}

\author{
Noraniza Md Jani ${ }^{1}$, Mohd Hafiz Zakaria ${ }^{2}$, Zulisman Maksom ${ }^{3}$ \\ Fakulti Teknologi Maklumat dan Komunikasi, \\ Universiti Teknikal Malaysia Melaka, Malaysia
}

\author{
Md. Shariff M. Haniff ${ }^{4}$ \\ Faculty of Business and Management, \\ Universiti Teknologi MARA \\ (Alor Gajah Campus), Melaka, Malaysia
}

\author{
Ramlan Mustapha ${ }^{5}$ \\ Institute of Teacher Education, Tengku Ampuan Afzan \\ Campus, Kuala Lipis, \\ Pahang, Malaysia
}

\begin{abstract}
The concept of online customer engagement is getting imperative in modern business due to the uncontrolled conversation via cyber-avenue. This study validates the antecedents of customer engagement conceptualized in Social Networking Sites (SNS) by benefitting the Fuzzy Delphi method. Through purposive sampling, a total of 12 experts from academics and practitioners have participated in the verification of items through 7-point linguistic scales of the questionnaire instrument. The findings show that invited experts have reached agreement on the elements shown within the framework through a $75 \%$ percent agreement for each construct. The analysis of this study has highlighted the implications of the relevant theories on the direction and the new dimensions of customer engagement concept especially in SNS to future researchers. Businesses are clearly able to gain stronger knowledge and information about their customer-related factors and their prospects at SNS.
\end{abstract}

Keywords-Customer engagement; antecedents; fuzzy delphi; SNS; online community

\section{INTRODUCTION}

The rapid emergence of mobile devices and applications have provided options and power for customers in brand communities of Social Networking Sites (SNS) to participate in market conversations. Varieties of proliferated social data have generated User-Generated-Content (UGC) in which manifesting dialogues among experienced and new customers as well as information seekers who are looking for valuable product reviews and knowledge. SNS major worldwide currently are Facebook, Instagram, YouTube, Qzone and Weibo [1]. Facebook, as a leading site, has served as an effective platform for many top brands to set up a page with an important goal of connecting with customers and maintaining two-way communication [2]-[3].

Firms typically use SNS by creating corporate profiles through brand pages to place and reinforce their brand and disseminate information about products. This brand page will aggregate the brand community to perform activities, among which most often are experience sharing of brands and products [4], thoughts and opinions [5], a sense of satisfaction over brands and firms [6], [15] and sentiment expressions [7] circulated through the electronic Word-of-Mouth (eWOM) mechanism.

On different notes, businesses are losing more control over their customers as online communities comprising peers, new and experienced members are interacting and influencing each other when making decisions about the use of brands and products based on information that becomes a matter of conversation [8]-[10]. Therefore, a different approach is required to measure the SNS marketing investment. Firms must change the approachable ways to new dimensions that focus on retaining, sustaining, and nurturing their prospects and existing customers [11]-[12] as customer insights remain a top research priority especially among practitioners [13]. On top of that awareness, many firms prioritise customer engagement activities as their main agenda in SNS digital medium. As the firm's key focus has shifted to customers, SNS is crucial as an intermediate medium capable of reaching greater promotion and campaigning for larger audiences, facilitating and accelerating customer service, raising awareness to new customers and prospects and facilitating the sharing of ideas and information from marketers and followers in an online community [14]-[16]. The Facebook and Instagram sites that have an increasingly significant number of active users in each month [1], [17]-[18] have been able to engage in many prospects and help retain customers through community participation in brand sites.

Research in recent years has explored customer engagement not just in theoretical but in an empirical ways by scholars and practitioners alike. This emerging concept can be approached and conceptualized in different dimensions, definition and object. However, this study, by its own lens, is focus to embrace it as a behavioural manifestation [19]-[20], [23] as an attempt to aggregate multiple ways that might influence the firm [21]-[23]. Besides affective and cognitive dimensions, behaviours remain strong indicators of engagement, in addition they manifest in a number of ways on social media [20]. Furthermore, the plethora of emergence social media are giving potentials for more research to be conducted in order to explain the customer engagement behaviour [24]-[27]. 
Customer engagement in an online community has been defined by this study as "a customer's behavioural manifestations that go beyond transactions and have a brand or firm focus, allow firms to involve specific interactive experiences within the online community, to build long-term relationship, and create more meaningful and sustainable interactions between the brand and/or the brand community and the customer, or among customers, resulting from motivational drivers" [19], [21]-[22], [28]. The motivations that drive customers to be engaged may comprise attitudinal factors such as their own goals, satisfaction, and trust, social benefits such as brand-relationship and interaction, economic benefits such as reward, and other expecting benefits such as enhanced knowledge and reputation [19], [29].

Previous empirical studies on customer engagement behaviour on SNS are still scarce [30]. Only a few researches have been known to explore the relevant elements of online customer engagement at SNS community [31]-[34], moreover, their research extends to many dimensions and is not limited to behavioural factor. Meanwhile a considerable numbers of the related works were focused on more generic engagement in social media and web platform [35]-[37]. There are researchers concentrate only on the specific elements of engagement in digital spaces (see [38]-[39]). On the other hand, some studies suggest many elements and are presented in the theoretical approach, but their study does not provide any primary data (see [19], [21]). Thanks for a few research on providing the diverse mixed scales for user engagement in SNS, nevertheless they were revealing the validation evidence from the previous works and not empirically tested the new specific context (see [40]). Less scientific studies cover more holistic aspects, such as verifying multi-dimensional factors that induce customer engagement in the behavioural dimension on SNS. As there are limited works on harnessing mechanism to measure this perspective [37], this study investigates the validation of the proposed customer engagement framework via Fuzzy Delphi technique.

\section{PURPOSE OF THE STUDY}

The present study was conducted to obtain a consensus of experts relating to the development and validity of the proposed diverse constructs in which is being called antecedents for the SNS customer engagement framework in Malaysian context. In the knowledge of this study, the Fuzzy Delphi technique works well as a research instrument to elucidate the agreement of experts on the examined questions [41]-[42] and to improve the understanding of an incomplete knowledge about a phenomenon [43]. Therefore, this effective tool is intentionally applied in the study to answer the research questions as follows:

1) What is the level of agreement among experts on the conceptualized SNS customer engagement framework?
2) What is the level of agreement among experts towards the indicators for antecedents of customer engagement via the SNS platform?

\section{CONCEPTUAL FRAMEWORK}

A considerable numbers of authors have highlighted customer engagement as a core role that has an array of antecedents, thus mediating the effects to the other consequences (see [19], [44]-[48]). Antecedents are lined up by decisive factors that stimulate customers to engage with brands and/or brand communities. Understanding the antecedents of customer engagement is important since it is likely to provide significant managerial guidance for firms regarding how to make their SNS efforts in brand/products offerings useful and influential for customers. Consequently, brands can take many benefits from their engagement activities to attract greater attention from the SNS community. For example, when satisfied customers share their positive experiences with products among Facebook contacts, it is likely that brand followers will increase dramatically, making friends or prospects affected or willing to engage with the brand via like or follow indicators on the board of SNS brand page.

Although the marketing communication and socialization offered in online engagement still cannot be replaced by an offline medium [30], it has been observed that online and offline world are closely linked in which business activities in the offline world will be eventually reflected in their online activities [49]. Either in the digital or offline environment, the determinants towards an engagement is very cross-related. In that case, this study validated the multi-dimensional operational structure of customer engagement as found in the existing literature in both online and offline marketing mechanism [28], [48].

This study is taking an inspiration from the past relevant and established research in engagement's domain to build up the conceptual framework. This one-layer conceptual framework consists of ten antecedents believed to have a very significant effect on the involvement of SNS online customers. By exploring conceptual and empirical research as being shown in Table I, the initiative has taken an approach to collectively examine a set of well-cited antecedents (Trust, Commitment, Interaction, Brand Post, Reward, and Satisfaction) that drives customer engagement, combined with the newly determined in which is a gap to previous researchers (Perceived Relationship, Information Platform and Processes, Consumption Goal, and Reputation). This way of integration will highlight the diverse set of multi-dimensional drivers of customer engagement (antecedents) with the aim of looking into the positive future anticipation from experts. 
TABLE I. ANTECEDENTS OF CUSTOMER ENGAGEMENT

\begin{tabular}{|c|c|c|c|c|c|c|c|c|c|c|c|}
\hline \multirow[b]{2}{*}{ Author(s) } & \multicolumn{10}{|c|}{ Antecedents of customer engagement } & \multirow[b]{2}{*}{$\begin{array}{l}\text { Context, } \\
\text { research type }\end{array}$} \\
\hline & 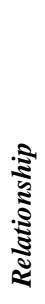 & 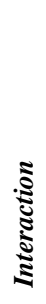 & $\hat{\Sigma}$ & 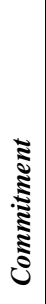 & 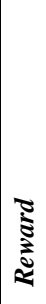 & 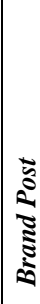 & 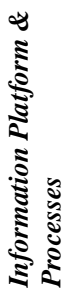 & 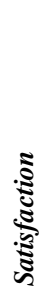 & 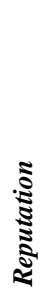 & 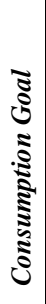 & \\
\hline [19] & & & $\sqrt{ }$ & $\sqrt{ }$ & & & $\sqrt{ }$ & $\sqrt{ }$ & & $\sqrt{ }$ & $\begin{array}{l}\text { Offline, } \\
\text { conceptual }\end{array}$ \\
\hline [21] & & & $\sqrt{ }$ & $\sqrt{ }$ & & & & $\sqrt{ }$ & & & $\begin{array}{l}\text { Offline, } \\
\text { conceptual }\end{array}$ \\
\hline [38] & & $\sqrt{ }$ & & & & & & & & & $\begin{array}{l}\text { Online social } \\
\text { platform, } \\
\text { conceptual }\end{array}$ \\
\hline [28] & & $\sqrt{ }$ & & & & & & & & & $\begin{array}{l}\text { Offline, } \\
\text { conceptual }\end{array}$ \\
\hline [50] & $\sqrt{ }$ & $\sqrt{ }$ & & $\sqrt{ }$ & & & & $\sqrt{ }$ & & & $\begin{array}{l}\text { Social media, } \\
\text { conceptual }\end{array}$ \\
\hline [10] & & & & & $\sqrt{ }$ & $\sqrt{ }$ & & & & & $\begin{array}{l}\text { Online brand } \\
\text { community, } \\
\text { conceptual }\end{array}$ \\
\hline [30] & $\sqrt{ }$ & $\sqrt{ }$ & & & & $\sqrt{ }$ & & & & & $\begin{array}{l}\text { SNS, } \\
\text { empirical }\end{array}$ \\
\hline [71] & & & & & & & & $\sqrt{ }$ & & & $\begin{array}{l}\text { Online brand } \\
\text { community, } \\
\text { empirical }\end{array}$ \\
\hline [32] & & & & & $\sqrt{ }$ & & & & & & $\begin{array}{l}\text { Online brand } \\
\text { community, } \\
\text { empirical }\end{array}$ \\
\hline [20] & $\sqrt{ }$ & & $\sqrt{ }$ & & $\sqrt{ }$ & $\sqrt{ }$ & & $\sqrt{ }$ & & & $\begin{array}{l}\text { Online brand } \\
\text { community, } \\
\text { empirical }\end{array}$ \\
\hline [46] & & & $\sqrt{ }$ & $\sqrt{ }$ & & & & $\sqrt{ }$ & & & $\begin{array}{l}\text { Social media, } \\
\text { empirical }\end{array}$ \\
\hline [39] & $\sqrt{ }$ & & & & & & & & & & $\begin{array}{l}\text { SNS, } \\
\text { empirical }\end{array}$ \\
\hline [33] & & & & & $\sqrt{ }$ & $\sqrt{ }$ & & & & & $\begin{array}{l}\text { SNS, } \\
\text { empirical }\end{array}$ \\
\hline [3] & & $\sqrt{ }$ & & & $\sqrt{ }$ & $\sqrt{ }$ & & & & & $\begin{array}{l}\text { SNS, } \\
\text { empirical }\end{array}$ \\
\hline [34] & & $\sqrt{ }$ & & & & $\sqrt{ }$ & & & & & $\begin{array}{l}\text { SNS, } \\
\text { empirical }\end{array}$ \\
\hline [48] & & & $\sqrt{ }$ & & & & & $\sqrt{ }$ & & & $\begin{array}{l}\text { Mobile } \\
\text { devices, } \\
\text { empirical }\end{array}$ \\
\hline [37] & & & & & & $\sqrt{ }$ & & & & & $\begin{array}{l}\text { Social media, } \\
\text { empirical }\end{array}$ \\
\hline
\end{tabular}

To a greater scholar extent, customer engagement is clearly advocated by the principle of relationship marketing theory in consumer behaviour research [50]-[51]. As the present study concerns online community platform, the definition of relationship marketing that has been employed by this study is closely linked to what [51] suggested that marketing is seen as a relationship, network, and interaction. Acting as a vehicle for the majority of businesses, past studies have proved social media, including SNS, as a key relationship marketing variable that leads to building and maintaining relational customers [52]. This principle theory are anchored with diverse theories of service-dominant logic, social exchange, and user gratification. Relationship marketing and its expansion theories were also embraced by many research work in different study context to cultivate meaningful relationships with customers and prospects, thus spotting the engagement [53].

Formed based on previous theories and works, this study postulates the conceptualization of customer engagement in SNS as illustrated in Fig. 1 below. The left box forms a group of ten antecedents that are argued as a determinant of customer motivation towards their engagement with the community and/or brand within the SNS pages. The following section of the methodology will describe the detailed sequence practiced to confirm these antecedents as the precise determinants of the customer engagement, as well as respond to the purpose of this study.

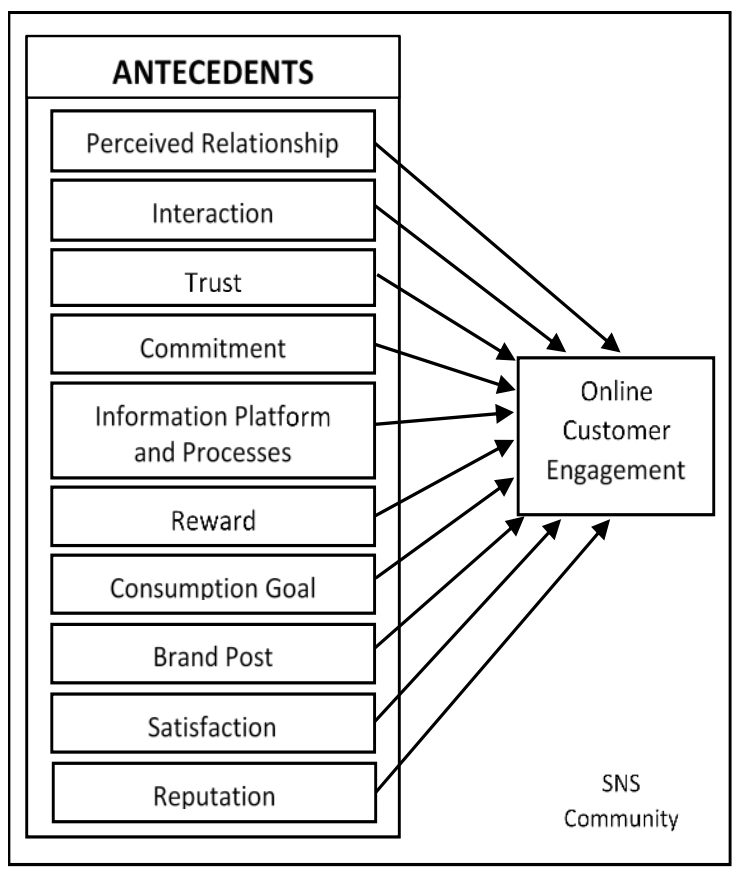

Fig. 1. Conceptual Framework of Customer Engagement in SNS

\section{Methodology}

This study has performed the Fuzzy Delphi technique to validate the conceptualized SNS customer engagement framework and the measurement scales throughout the whole research process. Successfully adopted in a wide variety of research variations including the IT/IS projects [43], it is a combination of traditional Delphi and Fuzzy set theory. This tool is a very helpful method when the level of research requires approval from a group of experts. Furthermore, Fuzzy Delphi technique is an attractive method to draw a collective decision on the blurred ideas as a result of the alignment of the opinions of the chosen experts [54].

While traditional Delphi uses infinite assessment rounds until experts' agreements are achieved, the new Fuzzy Delphi has the advantage of getting feedback in shorter time and lower costs, thereby increasing the number of survey results. Interestingly, experts can fully express their real reactions without misinterpretation to ensure completeness and consistency of opinion [56]. 


\section{A. Instrument Development}

The first phase of the Fuzzy Delphi technique began with the development of questionnaire scripts used for experts to verify the research items. The questionnaire was comprised with two parts: 1) demographics, and 2) 53 items of 7-Lickert point scales in 10 tested constructs or antecedents. The 7-point scale was chosen because the evidence shows that the higher the scales in the questionnaire, the more accurate the data obtained [41]. The measurement items are developed based on literature and further followed by a round of interviews by practitioners or real SMEs to confirm the verification of captured items [43].

\section{TABLE II. LIST OF CONSTRUCTS AND ADAPTED ITEM SOURCES}

\begin{tabular}{|l|l|l|}
\hline Antecedents & Adapted Scales & $\begin{array}{l}\text { Number of } \\
\text { item scales }\end{array}$ \\
\hline Perceived Relationship & {$[52]$} & 4 items \\
\hline Interaction & {$[58]-[59]$} & 8 items \\
\hline Trust & {$[57]$} & 8 items \\
\hline Commitment & {$[60]$} & 6 items \\
\hline $\begin{array}{l}\text { Information Platform and } \\
\text { Processes }\end{array}$ & {$[19]$} & 4 items \\
\hline Reward & {$[61]$} & 3 items \\
\hline Consumption Goal & {$[37]$} & 3 items \\
\hline Brand Post Characteristics & {$[33],[64]$} & 4 items \\
\hline Satisfaction & {$[48],[62]$} & 5 items \\
\hline Reputation & {$[63]$} & 8 items \\
\hline Total & & $\mathbf{5 3}$ items \\
\hline
\end{tabular}

In details, this has been achieved by three sequential steps. Initially, the SNS customer-conceptual framework of engagement was set up as illustrated in Figure 1. Second, the identified indicators are reviewed by practitioners through the individual close-interviews. Five SMEs were invited as participants in this stage with the task of assessing the reasonable aspect of engagement in the current practical context and then giving priority to each construct. Once they confirm agreement with the antecedents of customer engagement in SNS as shown, the final step is working with the determination of scale items for the engagement framework. Indicators for this purpose are taken from the comprehensive as well as relevant sources and adapted to be studied in relation to the brand and brand community engagement in SNS environment. Refer Table 2 for the list of adapted sources for each construct. These items are then collected and formatted into the form of a questionnaire to be disseminated to selected experts in the evaluation process.

\section{B. Data Collection and Analysis}

The second phase of the Delphi Fuzzy technique is critical in which the item scale in the questionnaire provided will be verified by the appointed experts and finally collected and analyzed. With the aim of achieving good results, this phase is implemented through five processes as follows:

\section{Respondents and sampling studies}

The purposive sampling is the best way in the experts' selection as the researcher wants to gain views and consensus on a matter [55]. Using this method, a total of 12 heterogeneous experts from different profiles and backgrounds were identified and invited to participate in the survey via a scheduled and face-to-face approach following the description procedures that may be required when issues arise from the items reviewed. This number of 12 respondents was taken from Gordon's suggestion [65] which states that heterogeneous sampling requires between 10 and 35 experts. They consist of two distinct groups: academician and practitioner. Comprising of 7 academicians and 5 practitioners representing SMEs, they have been identified to meet the criteria required as experts based on knowledge and experience with the issues being investigated, the ability and willingness to participate, the qualifications, the individual character, the comparative ability, the communication skills as well as the consistent and credible in their respective fields [54], [66], as shown in Table 3. To be more specific, these specialists are skilled in either one or more of these areas: IT, social media, online governance, marketing, and consumer behaviour.

TABLE III. CLASSIFICATION OF HETEROGENEOUS EXPERTS

\begin{tabular}{|l|l|l|}
\hline \multirow{2}{*}{ Experts } & Institution/Sector & $\begin{array}{l}\text { Number of } \\
\text { participants }\end{array}$ \\
\hline \multirow{4}{*}{ Academicians } & UTeM (IT domain) & 2 \\
\cline { 2 - 3 } & UTeM (Business domain) & 1 \\
\cline { 2 - 3 } & UITM (IT domain) & 1 \\
\cline { 2 - 3 } & UITM (Business domain) & 1 \\
\cline { 2 - 3 } & UPM (IT domain) & 1 \\
\cline { 2 - 3 } & Polytechnic (IT domain) & 1 \\
\hline \multirow{2}{*}{ Practitioners (SMEs) } & Manufacturing & 2 \\
\cline { 2 - 3 } & Services & 3 \\
\hline \multicolumn{2}{|l|}{ Total } & $\mathbf{1 2}$ \\
\hline
\end{tabular}

On each item provided in the questionnaire of 7-Lickert scale assessment, feedback is obtained from each expert through the marking scales 1 to 7 to show the level of agreement. They are also provided by the particular spaces at each construct for any suggestion to upgrade the accuracy and relevancy of questions. The forms then collected by hand and the item scales were analysed by applying Fuzzy Delphi in the spreadsheet of Microsoft Excel.

TABLE IV. 7-LICKERT FUZZY SCALES OF AGREEMENT LEVEL

\begin{tabular}{|l|l|l|l|}
\hline Linguistic variables & \multicolumn{3}{l|}{ Fuzzy scales } \\
\hline Strongly Disagree & 0.0 & 0.0 & 0.1 \\
\hline Disagree & 0.0 & 0.1 & 0.3 \\
\hline Somewhat Disagree & 0.1 & 0.3 & 0.5 \\
\hline Neither agree or disagree & 0.3 & 0.5 & 0.7 \\
\hline Somewhat agree & 0.5 & 0.7 & 0.9 \\
\hline Agree & 0.7 & 0.9 & 1.0 \\
\hline Strongly agree & 0.9 & 1.0 & 1.0 \\
\hline
\end{tabular}

\section{The Determination of Linguistic Variables and Average} Responses

After obtaining the response from the selected respondents, all linguistic variables in the form of 7-Lickert scales were transformed to triangular fuzzy numbers [70], as displayed in Table IV. Triangular Fuzzy Numbers represent the value of $m_{1}$ (minimum value), $m_{2}$ (simple value), and $m_{3}$ (maximum value) written as $\left(m_{1}, m_{2}, m_{3}\right)$. The average value of each expert's response will then be calculated with the following equation (1) as below: 


$$
m=\frac{\sum_{1}^{n} m_{i}}{n}
$$

E. The determination of threshold value " $d "$

To identify the level of agreement between experts, the threshold value between two Fuzzy numbers $\left(m=m_{1}, m_{2}\right.$, $\left.m_{3}\right)$ and $\left(n=n_{1}, n_{2}, n_{3}\right)$ will be calculated using the given formula equation (2) :

$$
\begin{aligned}
& d(\bar{m}, \bar{n}) \\
& \left.=\sqrt{\frac{1}{3}\left[\left(m_{1}-n_{1}\right)^{2}+\left(m_{2}-n_{2}\right)^{2}+\left(m_{3}-n_{3}\right)^{2}\right]}\right]
\end{aligned}
$$

According to [67]-[68], the "threshold" ("d") value must be $<=0.2$ to reach an agreement of all experts.

\section{F. The Determination of Percentage of Group Consensus}

Afterwards, the overall value of the items in each construct are computed to ensure the percentage must exceed $75 \%$ to achieve the group agreement [67]. Otherwise the second round of this technique should be implemented. The formula is as below:

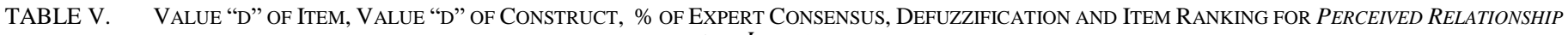
AND INTERACTION

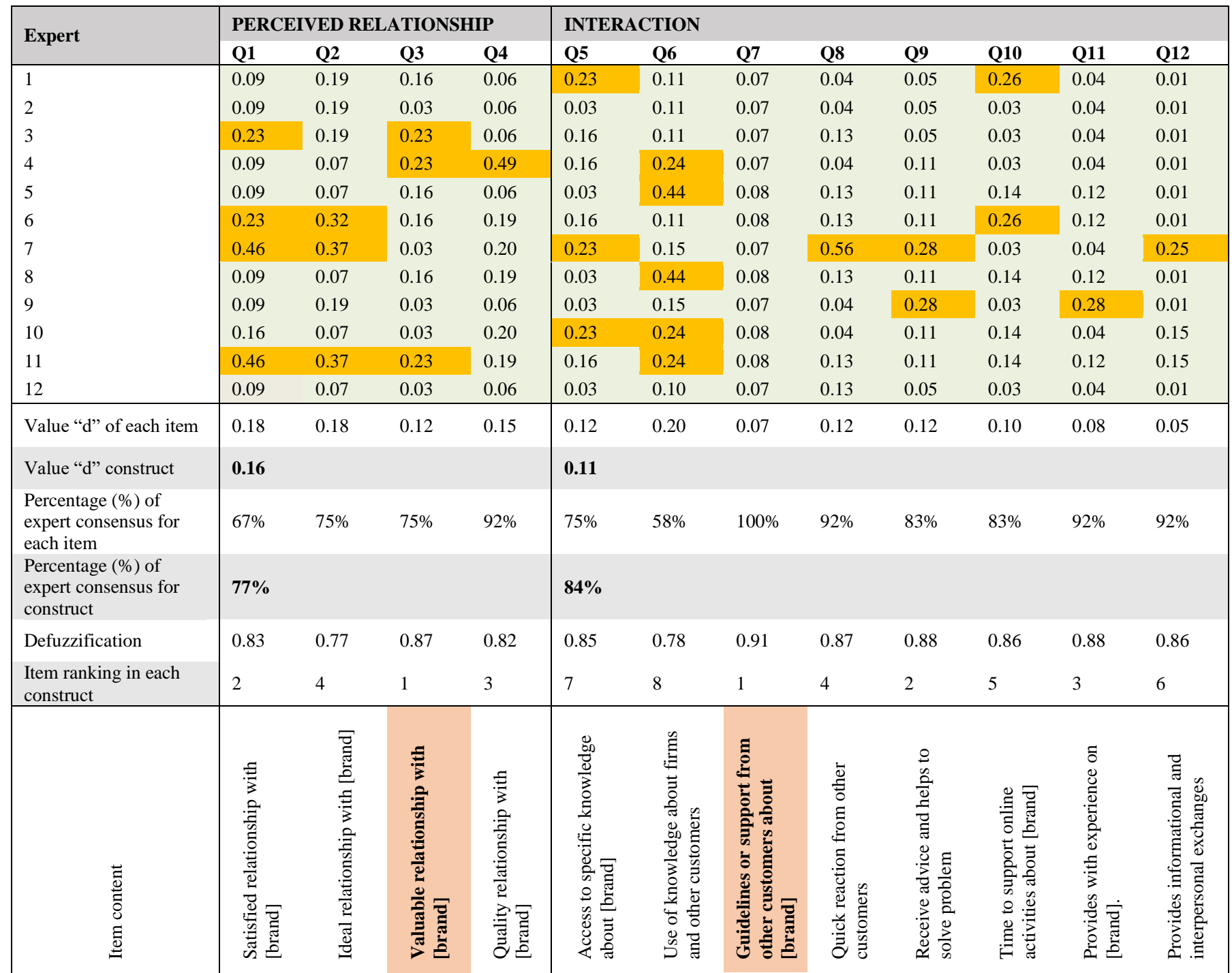

G. The Identification of Defuzzification and Ranking of Items

According to [69], approximation of a fuzzy set by an $\alpha$ cut (alpha-cut) is the oldest and the simplest defuzzification method. The value of $\alpha=0.5$ is the median of interval $[0,1]$. To calculate the defuzzification score, there are three formulas that can be used (choose either i, ii or iii):

\begin{tabular}{|c|l|}
\hline i & $A_{\max }=\frac{m_{1}+m_{2}+m_{3}}{3}$ \\
\hline ii & $A_{\max }=\frac{m_{1}+2 m_{2}+m_{3}}{4}$ \\
\hline iii & $A_{\max }=\frac{m_{1}+4 m_{2}+m_{3}}{6}$ \\
\hline
\end{tabular}


The resulting score numbers (defuzzification scores) must be in the range 0 to 1 [41] and the value of $\alpha$-cut must be exceeding 0.5 [69]-[70] to indicate the expert consensus. The present work can identify the priorities of the constructs and items according to the scores obtained.

\section{RESULT}

The Fuzzy Delphi analysis on the present study has shown a satisfactory and good overall outcome. Following are the result of the "d" value obtained from each antecedent's item (see Table V, Table VI, Table VII, and Table VIII). The box marked with " $\mathrm{d}$ " values exceeds 0.2 , indicating that there are experts who are at the midst of agree and disagree with the items submitted in the questionnaire. However, the most unchecked boxes conclude that the items are relevant and agreeable to the experts. The first two constructs, Perceived Relationship and Interaction, has an average value of "d" threshold of less than 0.2. Accordingly, both have reached the percentage of expert consensus of more than $75 \%$, and the defuzzification scores greater than 0.5, making them acceptable as antecedents for the customer engagement concept studied.

According to expert opinion, not all adapted items from the literature are applicable in the context of the SNS community to be studied. For example, the calculation template was attempted to adjust towards two constructs, namely Trust and Commitment (refer Table VI). This study has removed 3 items from Trust due to the low \% of " $\mathrm{d}$ " value, leaving only 5 as valid questions to measure this construct. That action was done to able the whole \% item "d" $\leq 0.2$ has achieved the agreement of $78 \%$, making this construct successfully maintained. However, the removal of items from the Commitment due to the low\% " $\mathrm{d}$ " value still does not support agreements on this construct to reach $75 \%$. Therefore, it has to be removed from the framework.

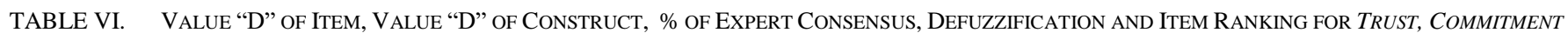
AND CONSUMPTION GOAL

\begin{tabular}{|c|c|c|c|c|c|c|c|c|c|c|c|c|}
\hline \multirow{2}{*}{ Expert } & \multicolumn{5}{|c|}{ TRUST } & \multicolumn{4}{|c|}{ COMMITMENT } & \multicolumn{3}{|c|}{ CONSUMPTION GOAL } \\
\hline & Q13 & Q14 & Q15 & Q16 & Q17 & & & & & Q18 & Q19 & Q20 \\
\hline 1 & 0.12 & 0.19 & 0.10 & 0.09 & 0.18 & 0.18 & 0.12 & 0.14 & 0.24 & 0.03 & 0.05 & 0.03 \\
\hline 2 & 0.12 & 0.05 & 0.06 & 0.09 & 0.06 & 0.06 & 0.12 & 0.14 & 1.10 & 0.03 & 0.05 & 0.03 \\
\hline 3 & 0.12 & 0.19 & 0.10 & 0.22 & 0.18 & 0.18 & 0.25 & 0.26 & 0.25 & 0.03 & 0.05 & 0.13 \\
\hline 4 & 0.13 & 0.20 & 0.29 & 0.17 & 0.21 & 0.21 & 0.15 & 0.42 & 0.09 & 0.03 & 0.05 & 0.03 \\
\hline 5 & 0.12 & 0.05 & 0.10 & 0.22 & 0.18 & 0.18 & 0.25 & 0.26 & 0.36 & 0.12 & 0.11 & 0.13 \\
\hline 8 & 0.12 & 0.05 & 0.10 & 0.22 & 0.18 & 0.18 & 0.25 & 0.26 & 0.36 & 0.12 & 0.11 & 0.13 \\
\hline 9 & 0.13 & 0.20 & 0.10 & 0.46 & 0.21 & 0.21 & 0.44 & 1.00 & 0.09 & 0.03 & 0.05 & 0.03 \\
\hline 10 & 0.13 & 0.20 & 0.06 & 0.17 & 0.50 & 0.50 & 0.44 & 0.14 & 0.09 & 0.03 & 0.11 & 0.13 \\
\hline 11 & 0.43 & 0.19 & 0.10 & 0.17 & 0.18 & 0.18 & 0.15 & 0.26 & 0.32 & 0.12 & 0.11 & 0.27 \\
\hline $\begin{array}{l}\text { Percentage (\%) of expert } \\
\text { consensus for each item }\end{array}$ & $83 \%$ & $100 \%$ & $83 \%$ & $58 \%$ & $67 \%$ & $45 \%$ & $36 \%$ & $27 \%$ & $55 \%$ & $92 \%$ & $92 \%$ & $83 \%$ \\
\hline $\begin{array}{l}\text { Percentage }(\%) \text { of expert } \\
\text { consensus for construct }\end{array}$ & $78 \%$ & & & & & $41 \%$ & & & & $89 \%$ & & \\
\hline Defuzzification & 0.81 & 0.82 & 0.89 & 0.82 & 0.83 & & & & & 0.88 & 0.89 & 0.90 \\
\hline $\begin{array}{l}\text { Item ranking in each } \\
\text { construct }\end{array}$ & 5 & 3 & 1 & 4 & 2 & NOT & MPU & & & 3 & 2 & 1 \\
\hline 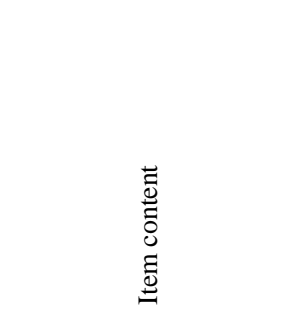 & 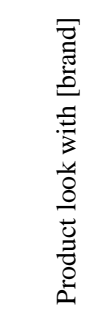 & 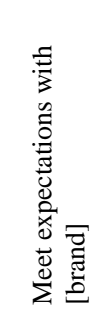 & 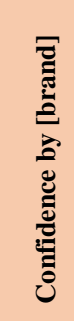 & 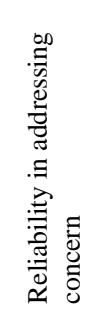 & 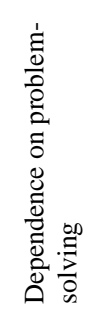 & & & $\sum_{\substack{x \\
\frac{x}{2}}}^{0}$ & & 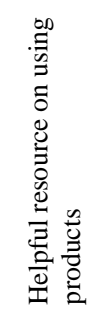 & 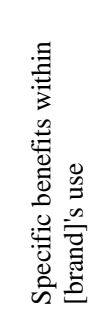 & 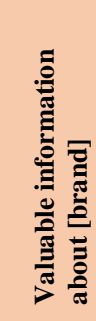 \\
\hline
\end{tabular}


The next six constructs (Consumption Goal, Reward, Brand Post, Information Platform and Processes, Satisfaction and Reputation) displayed through Table VII and Table VIII have a generous overall outlook after being analysed. Each obtained average value " $d$ " beyond 0.2 [67]-[68], the percentage of experts' agreement surpassed 75\% [67], as well as the defuzzification that exceeds 0.5 [69]-[70]. These results confirm that all of these constructs are influential as a determinant of a customer's engagement through the SNS platform.

Given the findings, 9 constructs for antecedents of customer engagement are having consensus among experts, showing by the "d" $<=0.2$ [67]-[68] and the overall percentage " $\mathrm{d}$ " $<=0.2$ exceeding 75\% [67]. However, one of the antecedents (Commitment) is analyzed as unsuccessfully beyond the agreement of the experts involved. According to the results of defuzzification in Tables V - VIII, the scores obtained for all items of antecedents not including Commitment, are within the range of 0 to 1 and the $\alpha$-cut values have exceeded 0.5 [41], [69]-[70]. From the aspect of item updating, Fuzzy Delphi analysis has resulting the reduction of 9 out of 53 items reviewed by the expert group, bringing the current amount of items to 44 (labelled by Q1 Q44 in Tables V - VIII). This has resulted in a collective question that is really appropriate and useful to target the objective of the actual study on the next level.

TABLE VII. VALUE “D” OF ITEM, VALUE “D” OF CONSTRUCT, \% OF EXPERT CONSENSUS, DEFUZZIFICATION AND ITEM RANKING FOR REWARD, BRAND POST AND INFORMATION PLATFORM AND PROCESSES

\begin{tabular}{|c|c|c|c|c|c|c|c|c|c|c|c|}
\hline \multirow{2}{*}{ Expert } & \multicolumn{3}{|c|}{ REWARD } & \multicolumn{4}{|c|}{ BRAND POST } & \multicolumn{4}{|c|}{ INFO PLATFORM \& PROCESSES } \\
\hline & Q21 & Q22 & Q23 & Q24 & Q25 & Q26 & Q27 & Q28 & Q29 & Q30 & Q31 \\
\hline 1 & 0.14 & 0.04 & 0.05 & 0.04 & 0.03 & 0.04 & 0.04 & 0.06 & 0.16 & 0.06 & 0.06 \\
\hline 2 & 0.05 & 0.04 & 0.05 & 0.04 & 0.03 & 0.04 & 0.04 & 0.06 & 0.11 & 0.06 & 0.06 \\
\hline 3 & 0.14 & 0.14 & 0.16 & 0.04 & 0.03 & 0.04 & 0.04 & 0.10 & 0.23 & 0.10 & 0.10 \\
\hline 4 & 0.25 & 0.04 & 0.23 & 0.56 & 0.23 & 0.54 & 0.54 & 0.30 & 0.45 & 0.30 & 0.06 \\
\hline 5 & 0.14 & 0.14 & 0.16 & 0.13 & 0.16 & 0.15 & 0.15 & 0.10 & 0.23 & 0.10 & 0.10 \\
\hline 6 & 0.14 & 0.14 & 0.16 & 0.13 & 0.16 & 0.15 & 0.15 & 0.10 & 0.23 & 0.10 & 0.10 \\
\hline 7 & 0.25 & 0.26 & 0.23 & 0.04 & 0.23 & 0.24 & 0.24 & 0.06 & 0.16 & 0.06 & 0.06 \\
\hline 8 & 0.14 & 0.14 & 0.16 & 0.13 & 0.16 & 0.15 & 0.15 & 0.10 & 0.23 & 0.10 & 0.10 \\
\hline 9 & 0.54 & 0.55 & 0.53 & 0.04 & 0.03 & 0.04 & 0.04 & 0.06 & 0.45 & 0.06 & 0.06 \\
\hline 10 & 0.14 & 0.14 & 0.16 & 0.13 & 0.23 & 0.15 & 0.15 & 0.10 & 0.16 & 0.10 & 0.10 \\
\hline 11 & 0.14 & 0.14 & 0.16 & 0.13 & 0.16 & 0.15 & 0.15 & 0.10 & 0.23 & 0.10 & 0.10 \\
\hline 12 & 0.05 & 0.04 & 0.05 & 0.04 & 0.03 & 0.04 & 0.04 & 0.06 & 0.11 & 0.06 & 0.30 \\
\hline Value "d" of each item & 0.18 & 0.15 & 0.17 & 0.12 & 0.12 & 0.14 & 0.14 & 0.10 & 0.23 & 0.10 & 0.10 \\
\hline Value “d” construct & 0.17 & & & 0.13 & & & & 0.13 & & & \\
\hline $\begin{array}{l}\text { Percentage }(\%) \text { of expert } \\
\text { consensus for each item }\end{array}$ & $75 \%$ & $83 \%$ & $75 \%$ & $92 \%$ & $75 \%$ & $83 \%$ & $83 \%$ & $92 \%$ & $42 \%$ & $92 \%$ & $92 \%$ \\
\hline $\begin{array}{l}\text { Percentage }(\%) \text { of expert } \\
\text { consensus for construct }\end{array}$ & $78 \%$ & & & $\mathbf{8 3} \%$ & & & & $79 \%$ & & & \\
\hline Defuzzification & 0.86 & 0.85 & 0.87 & 0.87 & 0.85 & 0.85 & 0.85 & 0.90 & 0.78 & 0.90 & 0.92 \\
\hline $\begin{array}{l}\text { Item ranking in each } \\
\text { construct }\end{array}$ & 2 & 3 & 1 & 1 & 2 & 3 & 4 & 2 & 4 & 3 & 1 \\
\hline 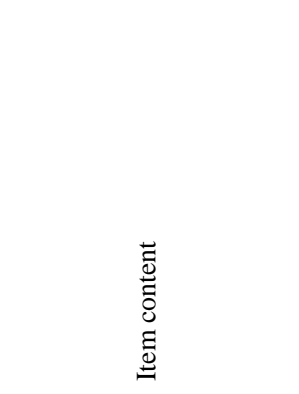 & 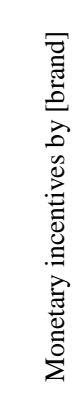 & 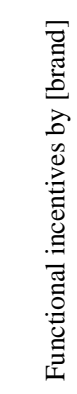 & 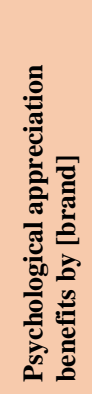 & 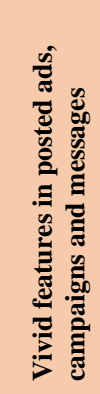 & 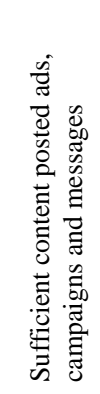 & 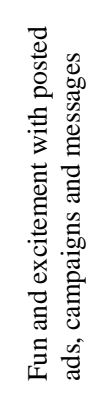 & 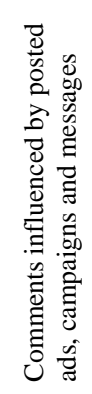 & 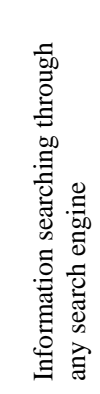 & 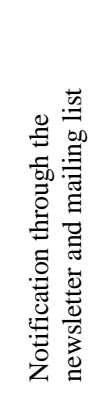 & 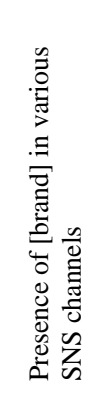 & 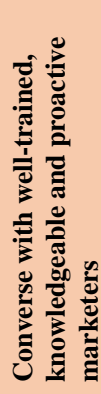 \\
\hline
\end{tabular}




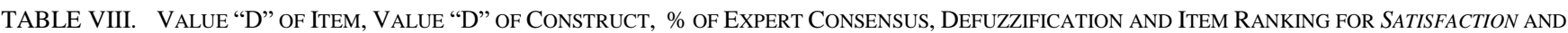
REPUTATION

\begin{tabular}{|c|c|c|c|c|c|c|c|c|c|c|c|c|c|}
\hline \multirow{2}{*}{ Expert } & \multicolumn{5}{|c|}{ SATISFACTION } & \multicolumn{8}{|c|}{ REPUTATION } \\
\hline & Q32 & Q33 & Q34 & Q35 & Q36 & Q37 & Q38 & Q39 & Q40 & Q41 & Q42 & Q43 & Q44 \\
\hline 1 & 0.08 & 0.05 & 0.22 & 0.12 & 0.15 & 0.11 & 0.16 & 0.06 & 0.05 & 0.23 & 0.04 & 0.03 & 0.03 \\
\hline 2 & 0.08 & 0.05 & 0.09 & 0.12 & 0.15 & 0.05 & 0.05 & 0.06 & 0.05 & 0.05 & 0.04 & 0.03 & 0.03 \\
\hline 3 & 0.16 & 0.14 & 0.16 & 0.18 & 0.21 & 0.11 & 0.16 & 0.10 & 0.11 & 0.16 & 0.15 & 0.13 & 0.13 \\
\hline 4 & 0.18 & 0.21 & 0.17 & 0.14 & 0.10 & 0.05 & 0.05 & 0.06 & 0.05 & 0.05 & 0.04 & 0.03 & 0.03 \\
\hline 5 & 0.08 & 0.05 & 0.09 & 0.12 & 0.15 & 0.11 & 0.16 & 0.10 & 0.11 & 0.16 & 0.15 & 0.13 & 0.13 \\
\hline 6 & 0.08 & 0.18 & 0.09 & 0.12 & 0.15 & 0.11 & 0.16 & 0.10 & 0.11 & 0.16 & 0.15 & 0.13 & 0.13 \\
\hline 7 & 0.18 & 0.21 & 0.17 & 0.43 & 0.40 & 0.28 & 0.23 & 0.30 & 0.28 & 0.23 & 0.24 & 0.27 & 0.27 \\
\hline 8 & 0.08 & 0.05 & 0.09 & 0.12 & 0.15 & 0.11 & 0.16 & 0.10 & 0.11 & 0.16 & 0.15 & 0.13 & 0.13 \\
\hline 9 & 0.08 & 0.21 & 0.46 & 0.43 & 0.10 & 0.28 & 0.23 & 0.06 & 0.28 & 0.53 & 0.54 & 0.27 & 0.27 \\
\hline 10 & 0.47 & 0.05 & 0.17 & 0.14 & 0.10 & 0.05 & 0.53 & 0.06 & 0.05 & 0.05 & 0.04 & 0.03 & 0.03 \\
\hline 11 & 0.21 & 0.18 & 0.22 & 0.26 & 0.40 & 0.05 & 0.05 & 0.10 & 0.11 & 0.16 & 0.15 & 0.13 & 0.13 \\
\hline 12 & 0.08 & 0.05 & 0.09 & 0.12 & 0.15 & 0.11 & 0.16 & 0.10 & 0.11 & 0.16 & 0.04 & 0.03 & 0.03 \\
\hline Value "d" of each item & 0.15 & 0.12 & 0.17 & 0.19 & 0.19 & 0.12 & 0.17 & 0.10 & 0.12 & 0.17 & 0.14 & 0.11 & 0.11 \\
\hline Value "d" construct & 0.16 & & & & & 0.13 & & & & & & & \\
\hline $\begin{array}{l}\text { Percentage }(\%) \text { of expert } \\
\text { consensus for each item }\end{array}$ & $83 \%$ & $75 \%$ & $75 \%$ & $75 \%$ & $75 \%$ & $83 \%$ & $75 \%$ & $92 \%$ & $83 \%$ & $83 \%$ & $83 \%$ & $83 \%$ & $83 \%$ \\
\hline $\begin{array}{l}\text { Percentage }(\%) \text { of expert } \\
\text { consensus for construct }\end{array}$ & $77 \%$ & & & & & $83 \%$ & & & & & & & \\
\hline Defuzzification & 0.80 & 0.83 & 0.79 & 0.76 & 0.78 & 0.88 & 0.85 & 0.89 & 0.87 & 0.84 & 0.85 & 0.87 & 0.87 \\
\hline $\begin{array}{l}\text { Item ranking in each } \\
\text { construct }\end{array}$ & 2 & 1 & 3 & 5 & 4 & 2 & 6 & 1 & 3 & 8 & 7 & 4 & 5 \\
\hline 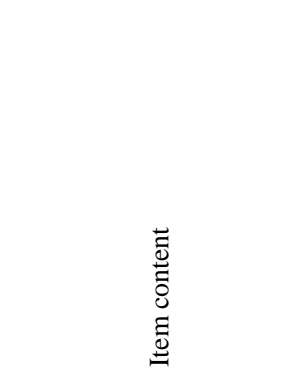 & 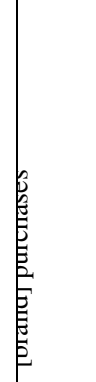 & 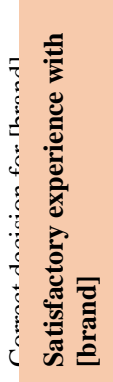 & 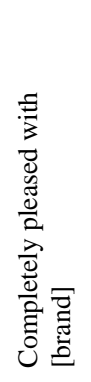 & 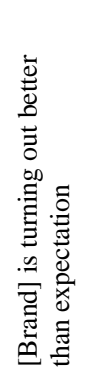 & 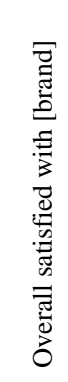 & 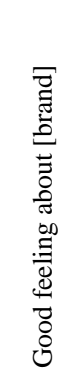 & 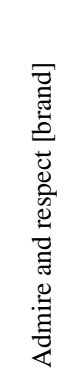 & 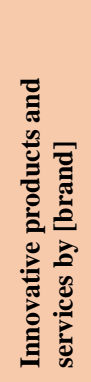 & 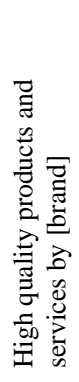 & 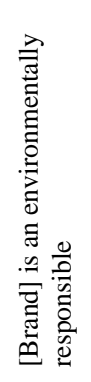 & 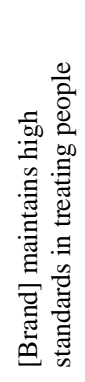 & 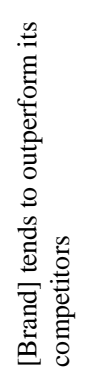 & 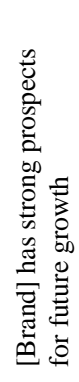 \\
\hline
\end{tabular}

VI. DISCUSSION AND CONCLUSION

It has been concluded that all the constructs (except Commitment) are maintained and certified as antecedents of online customer engagement at SNS based on the consensus of experts. Using Fuzzy Delphi analysis, this study has proven the importance of customer engagement emerging concept in a systematic and trusted approach. It demonstrates that antecedents obtained from literature are validated to be drivers of new as well as existing customers to engage with brand and/or brand communities in SNS environment. The findings of the study are in line with it's purpose to answer the questions pertaining to the agreement of experts on antecedents of customer engagement in popular SNS marketing channels. Therefore, the listed items are feasible and appropriate to be forwarded to the next study sample, consisting of active customers interacting with the SNS community for brand-related activities.

The defuzzification process is greatly used to filter the priority of items. In Perceived Relationship, valuable relationships with brand have the greatest contribution to enabling customer engagement in the SNS channel (refer to
Table V). For Interaction construct, experts have evaluated guidelines and support from firms and customers when interacting with SNS is the most important to engage someone (refer to Table V). Whereas in Trust, customers will only engage to the brands that he/she has a high level of confidence and can provide the services for problem-solving as being shown in Table VI. This table also displays that customers involved with SNS activities is hoping to aim valuable information acquisition in the first place from the point of view of brand and product use (see Consumption Goal).

Gathering psychological appreciation such as membership and entertainment in SNS brand community conversations have become the item that gets the most consent from experts (referring to the Reward in Table VII). In the same table, through the Brand Post dimension, the existence of vivid features in the ads, campaigns, and messages displayed through brand sites (including animations, different colors, videos, and pictures) also highlighted priorities over the other three items. Information Platform and Processes dimension show the most numerous deals from experts are through customer dependency with trained, knowledgeable and proactive marketers on the SNS brand page. Meanwhile, Table 
VIII shows the position of the customer's items in engaging with the brand within SNS through the antecedents of Satisfaction and Reputation. The result has confirmed that a satisfactory experience from existing customers dominates the expert agreement on Satisfaction. In parallel, factor Reputation concludes that innovative products and services by brands acquire the highest expert's choice.

The above findings clearly provide twice the implications. In view of the contribution of knowledge, research in online customer behaviour supports the limited, theoretical and empirical scientific materials, on the SNS platform. This finding can also be a space for future researchers who stick to the same theory (relationship marketing, service-dominant, social exchange and user gratification theories) to translate the conceptual elements in existing models into more useful practical studies. Fuzzy Delphi technique, as far as researcher knowledge, has not been used to verify the study material in the domain of customer engagement in SNS. Throughout the lens of this study, the Fuzzy Delphi method is proved to be the effective tool for validating the fuzzy items of multidimensional determinants for customer engagement, which are adapted from the literature with different context and setting. It also increases the statistical use of Fuzzy Delphi analysis among IT/IS research that has been proven extensively used before.

The study also offers practical implications that support important concepts to the business world such as customer engagement. In addition to the dominant elements in theories such as Trust, Reputation, and Satisfaction, stakeholders, especially business owners and marketers, need to take into account the other determinants dimensions that greatly affect digital subscribers to engage, such as the content and quality of postage advertisements published on the SNS interface, and the effectiveness of the delivery and information processing provided as an intermediary between their parties and customers. Firms accordingly can proactively cultivated the life cycle of marketing initiatives through the SNS channel where their brands and products need to be successfully maintained.

\section{ACKNOWLEDGEMENT}

The author would like to thank Universiti Teknikal Malaysia Melaka (UTeM) for providing research facilities at the time of conduction of this study and for the financial incentive for publishing this paper.

\section{REFERENCES}

[1] P. Kallas, "Top 15 Most Popular Social Networking Sites and Apps [August 2018]", Dreamgrow, 2018. [Online]. Available: https://www.dreamgrow.com/top-15-most-popular-social-networkingsites/. [Accessed: Sep. 16, 2018].

[2] L. Dokyun, K. Hosanagar and H. Sasikumar Nair, "The effect of social media marketing content on consumer engagement: evidence from Facebook. Available at SSRN, 2290802, 2018.

[3] I. Jamid UI and Z. Rahman, "Islam, Jamid Ul, and Zillur Rahman. "Linking customer engagement to trust and word-of-mouth on Facebook brand communities: An Empirical Study", Journal of Internet Commerce, vol. 15, no. 1, pp. 40-58, 2018.

[4] A. Sahabi Y and A. H. Busalim, "Antecedents of eWOM in social commerces", International Conference on Research and Innovation in Information Systems, ICRIIS. 2018, 2018, pp. 1-6.
[5] S. Chu and Y. Kim, "Determinants of consumer engagement in Electronic word-of-mouth (eWOM) in Social Networking Sites", International Journal of Advertising, vol. 30, no. 1, pp. 47-75, 2011.

[6] T. Aichner and F. Jacob, "Measuring the degree of corporate social media use," International Journal of Market Research, vol. 57, no. 2, pp. 257-275, 2015.

[7] Z. Zhang, X. Li, and Y. Chen, "Deciphering word-of-mouth in social media," ACM Transactions on Management Information Systems, vol. 3, no. 1, pp. 1-23, Apr. 2012.

[8] V. Blazevic et al., "Beyond traditional word-of-mouth: an expanded model of customer-driven influence." Journal of Service Management, vol. 24, no. 3, pp. 294-313, 2013.

[9] T. Hennig-Thurau, C. F. Hofacker, and B. Bloching, "Marketing the pinball way: understanding how social media change the generation of value for consumers and companies," Journal of Interactive Marketing, vol. 27, no. 4, pp.237-241, 2013.

[10] J. Wirtz et al., "Managing brands and customer engagement in online brand communities," Journal of Service Management, vol. 24, no. 3, pp. 223-244, Jun. 2013.

[11] R. Hanna, A. Rohm, and V. L. Crittenden, "We're all connected: the power of the social media ecosystem." Business Horizons, vol. 54, no. 3, 265-73, 2011.

[12] S. D. Vivek, S. E. Beatty, and R. M. Morgan, "A generalized multidimensional scale for measuring customer engagement," Journal of Marketing Theory and Practice, vol. 22, no. 4, pp. 401-420, 2014.

[13] "2018-2020 Research Priorities : Cultivating the customer asset", Marketing Science Institute, 2018. [Online]. Available: http://www.msi.org/research/2018-2020-research-priorities/cultivatingthe-customer-asset/. [Accessed: Nov. 07, 2017].

[14] C. Yu-Ting, H. Yu and H. Lu, "Persuasive messages, popularity cohesion, and message diffusion in social media marketing", Journal of Business Research, vol. 68, no. 4, pp. 777-782, 2015.

[15] O. M. Zain and M. B. Saidu, "The customers satisfaction on retailers' brand products: a study on selected areas in Klang Valley," ProcediaEconomics and Finance, vol. 35, pp. 418-427, 2016.

[16] L. Carolyn A and T. Kim, "Predicting user response to sponsored advertising on social media via the technology acceptance model", Computers in human behavior, vol. 64, pp. 710-718, 2016.

[17] J. Titcomb, "Facebook now has 2 billion users, Mark Zuckerberg announces", Telegraph, $2017 . \quad$ [Online]. Available: https://www.telegraph.co.uk/technology/2017/06/27/facebook-now-has2-billion-users-mark-zuckerberg-announces/. [Accessed: Oct. 15, 2017].

[18] "Number of monthly active Facebook users worldwide as of 2nd quarter 2018 (in millions)", Statista, 2018. [Online]. Available: https://www.statista.com/statistics/264810/number-of-monthly-activefacebook-users-worldwide/. [Accessed: Aug. 12, 2018].

[19] J. Van Doorn et al., "Customer engagement behavior: theoretical foundations and research directions." Journal of Service Research, vol. 13 , no. 3, pp. 253-266, 2010.

[20] L. Dessart, C. Veloutsou, and A. Morgan-Thomas, "Consumer engagement in online brand communities: a social media perspective," Journal of Product \& Brand Management, vol. 24, no. 1, pp. 28-42, Mar. 2015.

[21] A. Ilic, R. J. Brodie, L. D. Hollebeek, and B. Juric, "Customer engagement: conceptual domain, fundamental propositions, and implications for research," Journal of Service Research, vol. 14, no. 3, pp. 252-271, 2011

[22] P. C. Verhoef, W. J. Reinartz, and M. Krafft, "Customer engagement as a new perspective in customer management," Journal of Service Research, vol. 13, no. 3, pp. 247-252, 2010.

[23] E. Jaakkola and M. Alexander, "The role of customer engagement behavior in value co-creation : a service system perspective," Journal of Service Research, vol. 17, no. 3, pp. 247-261, 2014.

[24] V. Kumar, L. Aksoy, B. Donkers, R. Venkatesan, T. Wiesel, and S. Tillmanns, "Undervalued or Overvalued Customers: Capturing Total Customer Engagement Value," Journal of Service Research, vol. 13, no. 3, pp. 297-310, 2010. 
[25] T. H. Bijmolt, M. Eisenbeiss, B. G. Hardie, A. Lemmens and P. Saffert, "Analytics for customer engagement." Journal of Service Research, vol. 13, no. 3, pp. 341-356, 2010.

[26] A. Javornik and A. Mandelli, "Behavioral perspectives of customer engagement: an exploratory study of customer engagement with three Swiss FMCG brands," Journal of Database Marketing \& Customer Strategy Management, vol. 19, no. 4, pp. 300-310, 2012.

[27] W. Kunz, L. Aksoy, H. Hall, Y. Bart, K. Heinonen, and R. Marketing, "Customer engagement in a big data world," Journal of Services Marketing, vol. 31, no. 2, pp. 1-39, 2017.

[28] S. D. Vivek, S. E. Beatty and R. M. Morgan, "Customer Engagement: Exploring customer relationships beyond purchase." Journal of Marketing Theory and Practice, vol. 20, no. 2, pp. 122-146, 2012.

[29] S. Nambisan and R. A. Baron, "Virtual customer environments: testing a model of voluntary participation in value co-creation activities," Journal of Product Innovation Management, vol. 26, no. 4, pp. 388-406, Jul. 2009.

[30] G. Greve, "ScienceDirect The moderating effect of customer engagement on the brand image - brand loyalty relationship," Procedia Social Behavior. Science, vol. 148, no. 148, pp. 203-210, 2014.

[31] M. R. Habibi, M. Laroche, and M.-O. Richard, "The roles of brand community and community engagement in building brand trust on social media," Computers in Human Behavior, vol. 37, pp. 152-161, 2014.

[32] B. J. Baldus, C. Voorhees, and R. Calantone, "Online brand community engagement: Scale development and validation," Journal of Business Research, vol. 68, no. 5, pp. 978-985, 2015.

[33] F. Kujur and S. Singh, "Engaging customers through online participation in social networking sites," Asia Pacific Management Review, vol. 22, no. 1, pp. 16-24, Mar. 2017.

[34] J. Gutiérrez-Cillán, C. Camarero-Izquierdo, and R. San José-Cabezudo, "How brand post content contributes to user's Facebook brand-page engagement. The experiential route of active participation," BRQ Business Research Quarterly, vol. 20, no. 4, pp. 258-274, 2017.

[35] A. Mollen, H. Wilson, M. Oxon, and C. Dipcompsci, "Engagement, Telepresence and Interactivity in Online Consumer Experience: Reconciling Scholastic and Managerial Perspectives," Journal of Business Research Special Issue Internet Customer Behavior, vol. 63, no. 910, pp. 919-925, 2010.

[36] D. E. Schultz and J. Peltier, "Social media's slippery slope: challenges, opportunities and future research directions," Journal of Research in Interactive Marketing, vol. 7, no. 2, pp. 86-99, May 2013.

[37] J. Carlson, M. Rahman, R. Voola, and N. De Vries, "Customer engagement behaviours in social media: capturing innovation opportunities," Journal of Services Marketing, vol. 32, no. 1, pp. 83-94, Feb. 2018.

[38] C. M. K. Cheung, M. K. O. Lee, and X.-L. Jin, "Customer Engagement in an Online Social Platform: A Conceptual Model and Scale Development." in Thirty Second International Conference on Information Systems, 2011.

[39] M. A. Bashir and N. A. Ali, "Impact of customer brand relationship through Facebook on the level of customer engagement," Pakistan Business Review, no. April 2016, pp. 159-178, 2016.

[40] L. Sigerson and C. Cheng, "Scales for measuring user engagement with social network sites: A systematic review of psychometric properties", Computers in Human Behavior, vol. 83, no. 2018, pp. 87-105, 2018.

[41] M. Mohd Jamil, S. Siraj, Z. Hussin, N. M. Noh and A. Arifin, Pengenalan asas kaedah Fuzzy Delphi dalam penyelidikan rekabentuk pembangunan. Minda Intelek, Bangi, 2014.

[42] M. Mohd Jamil, S. Siraj, Y. Farazila, M. N. Nurulrabihah, Z. Hussin and S. Ahmad Arifin. " Aplikasi teknik Fuzzy Delphi terhadap keperluan elemen keusahawanan bagi pensyarah kejuruteraan politeknik Malaysia." International Journal of Business and Technopreneurship, vol. 5, no. 1, pp. 135-150, 2015.

[43] S. Gregory, J, F. T. Hartman and J. Krahn, "The Delphi method for graduate research.", Journal of Information Technology Education: Research, vol. 6, pp. 1-21, 2007.
[44] R. C. Gambetti, G. Graffigna, and S. Biraghi, "The Grounded Theory approach to consumer-brand engagement," International Journal of Market Research, vol. 54, no. 5, pp. 659-687, 2012.

[45] L. D. Hollebeek, M. S. Glynn, and R. J. Brodie, "Consumer brand engagement in social media: conceptualization, scale development and validation," Journal of Interactive Marketing, vol. 28, no. 2, pp. 149165, May 2014.

[46] A. Abdullah and D. S. Siraj, "Brand equity through customer engagement in social media: a critical review," IOSR Journal of Business and Management, vol. 18, no. 08, pp. 38-46, 2016.

[47] F. J. Martínez-López, R. Anaya-Sánchez, S. Molinillo, R. AguilarIllescas, and I. Esteban-Millat, "Consumer engagement in an online brand community," Electronic Commerce Research and Applications, vol. 23, pp. 24-37, 2017.

[48] R. Thakur and S. P. Jain, "Customer engagement and online reviews," Journal of Retailing and Consumer Services, 41, pp.48-59, 2017.

[49] H. Marsden, Guard your reputation online. Smartebookshop, Birmingham, 2013.

[50] C. M. Sashi, "Customer engagement, buyer - seller relationships , and social media." Management decision, vol. 50, no. 2, pp. 253-272, 2012.

[51] E. Gummesson, "Making relationship marketing operational", International Journal of Service Industry Management, vol. 5, no. 5, pp. 5-20, 1994.

[52] M. Clark and J. Melancon, "The Influence of social media investment on relational outcomes: A relationship marketing perspective", International Journal of Marketing Studies, vol. 5, no. 4, pp. 132 - 140, 2013.

[53] K. Filo, D. Lock and A. Karg, "Sport and social media research: A review." Sport Management Review, vol. 18, no. 2, pp. 166-181, 2015.

[54] R. Mustapha and G. Darusalam, Aplikasi kaedah Fuzzy Delphi dalam Sains Sosial. University of Malaya Press, 2017.

[55] R. Mustapha, Z. Hussin and S. Siraj, "Analisis faktor penyebab ketidakjujuran akademik dalam kalangan mahasiswa: aplikasi teknik Fuzzy Delphi.", Jurnal Kurikulum \& Pengajaran Asia Pasifik, vol. 2, no. 2, pp. 1-17, 2017.

[56] N. Mat Noh, S. Abd Razak, N. Alias, S. Siraj, M. Mohd Jamil and Z. Hussin, "Usage of Facebook : the future impact of curriculum implementation on students in Malaysia", Procedia-Social and Behavioral Sciences, vol. 103, pp. 1261-1270, 2013.

[57] E. Delgado-Ballester, J. L. Munuera-Aleman and M. J. Yague-Guillen, "Development and validation of a brand trust scale," International Journal of Market Research, vol. 45, no. 1, pp. 35-54, 2003.

[58] U. M. Dholakia, V. Blazevic, C. Wiertz, and R. Algesheimer, "Communal service delivery: how customers benefit from participation in firm-hosted virtual P3 communities," Journal of Service Research, 2009.

[59] T. Hennig-Thurau, K. P. Gwinner, G. Walsh, and D. D. Gremler, "Electronic word-of-mouth via consumer-opinion platforms: what motivates consumers to articulate themselves on the Internet?," Journal of Interactive Marketing, vol. 18, no. 1, pp. 38-52, Jan. 2004.

[60] A. Gustaffsson, M. D. Johnson, and I. Roos, "The effects of customer satisfaction, relationship commitment dimensions, and triggers on customer retention," Journal of Marketing, vol. 69, no. 4, pp. 210-218, 2006.

[61] H. Jang, L. Olfman, I. Ko, J. Koh and K. Kim, "The influence of online brand community characteristics on community commitment and brand loyalty." International Journal of Electronic Commerce, vol. 12, no. 3, pp. 57-80, 2008.

[62] J. J. Cronin, M. K. Brady, and G. T. M. Hult, "Assessing the effects of quality, value, and customer satisfaction on consumer behavioral intentions in service environments," Journal of Retailing, vol. 76, no. 2, pp. 193-218, 2000.

[63] C. J. Fombrun, N. A. Gardberg and J. M. Sever, "The Reputation QuotientSM: a multi-stakeholder measure of corporate reputation." Journal of Brand Management. vol. 7, no. 4, pp. 241-255, 2000.

[64] L. De Vries, S. Gensler, and P. S. H. Lee, "Popularity of brand posts on brand fan pages: an investigation of the effects of social media marketing," Journal of Interactive Marketing, vol. 26, pp. 83-91, 2012. 
[65] T. J. Gordon, The Delphi Method. Future Research Methodology, 1994.

[66] M. Adler and E. Ziglio, Gazing into the oracle: the Delphi Method and its application to social policy and public health. London: Jessica Kingsley Publishers, 1996.

[67] P. L. Chang, C. W. Hsu and P. C. Chang, "Fuzzy Delphi Method for evaluating hydrogen production technologies." International Journal of Hydrogen Energy. pp. 14172 - 14179, 2011.

[68] C.H. Cheng and Y. Lin, "Evaluating the best main battle tank using Fuzzy Decision Theory with linguistic criteria evaluation." European Journal of Operational Research, vol. 142, no. 1, pp. 174-186, 2002.
[69] S. Bodjanova, "Median alpha-levels of a Fuzzy Number." Fuzzy Sets and Systems. vol. 157, no. 7, pp. 879-891, 2006.

[70] C. W. Tang and C. T. Wu, "Obtaining a picture of undergraduate education quality: a voice from inside the university." Higher Education, vol. 60, pp. 269-286, 2010

[71] Dovaliene, A. Masiulyte, and Z. Piligrimiene, "The relations between customer engagement, perceived value and satisfaction: the case of mobile applications," Procedia-Social and Behavioral Sciences, vol. 213, pp. 659-664, Dec. 2015. 